\title{
Early Postfire Vegetation Dynamics of Shrub-steppe Communities (On the example of Burtinskaya Shrub-steppe of Orenburg Nature Reserve)
}

O G Kalmykova, G Kh Dusaeva, and N V Maksutova

Department of Landscape Ecology, Institute of Steppe, Ural Branch RAS, Orenburg, Russia

\section{Abstract}

The intensification of fire regime in the shrub-steppe determined the need for research aimed at identifying the regularities of the effect exerted by wildfires on shrub-steppe ecosystems and one of their most dynamic components referred to as plant cover. A present study was carried out on the territory of Burtinskaya Steppe of the Orenburg Reserve and in its protected area in 2015--2016, following the fire that occurred in August 2014. It was found out that in the first year following a fire event, the total plant cover of steppe ecosystems affected by a wildfire is almost halved. The

Corresponding Author:

O G Kalmykova

okstepposa@gmail.com

Received: 25 October 2019

Accepted: 15 November 2019

Published: 25 November 2019

Publishing services provided by

Knowledge E

(c) O G Kalmykova et al. This

article is distributed under the

terms of the

Attribution License, which

permits unrestricted use and

redistribution provided that the

original author and source are

credited.

Selection and Peer-review under the responsibility of the AgroSMART 2019 Conference Committee.
G OPEN ACCESS plant cover dominated by bunchgrasses, especially of the genus Stipa, significantly decreases, and the abundance and diversity of ephemeroids increase. The floristic alteration manifesting itself in the form of an invasive role of certain species (most often ephemeroids and biennials) during one vegetative stage is endemic to the areas exposed to overgrazing in the past. The outburning of plant cover can bring about a change in dominant and codominant plant species within a shrub-steppe assemblage.

Keywords: wildfires, shrub-steppe communities, Orenburg Nature Reserve.

\section{Introduction}

Grassland fires either directly or indirectly affecting the transformation of shrub-steppe ecosystems and the vegetation structure and composition have provoked considerable interest in studying fires and assessing their impact on shrub-steppe vegetation.

A boost of research activities to study the changes in the plant cover of the shrubsteppe after a fire occurred in the early $21^{\text {st }}$ century due to the widespread intensification of grassland fires. Experts from the shrub-steppe regions of Russia [1--6] and CIS [7--10] show a particular interest in the issue under review. The impact of a pyrogenic factor is of great importance and is also studied within landscape analogues of a shrub-steppe -- prairies, pampas and other grasslands [11--18].

Fire regimes are a component of human impact that can be difficult to control, even in a strict nature reserve. They tend to arise as a result of economic activity and rapidly 
spread from cross-border regions to a protected area. The last wildfire occurred by the time of the present study on the territory of the Burtinskaya Shrub-steppe of the Orenburg reserve in August 2014 and burned off 2,000 hectares of the reserved area.

The study of the structure and composition of shrub-steppe plant communities was carried out in 2015--2016 in the first years after the fire. They were part of a project to create a framework for monitoring ecosystems in a protected plot after a 2014 wildfire, supported by the UNDP/GEF/MNR RF "Modern Systems and Mechanisms for Managing PAs in the shrub-steppe biome of Russia."

\section{Methods and Materials}

The site occupied by Burtinskaya Shrub-steppe of the Orenburg Nature Reserve and its protected area were chosen as a model area for research. From a botanic and geographical perspective, this wildlife sanctuary is located in a subzone of forb-fescuefeather Transvolga-Kazakh steppes [19], from an asoil-geographic perspective -- in a southern black-earth subzone [20].

On the territory of the Burtinskaya Steppe, 7 fixed monitoring sites were selected in different environmental conditions and with excellent native vegetation. Within each site, paired communities separated by a fire edge were assessed, with 14 geobotanical descriptions to be made annually (two descriptions per a site -- one in postfire communities, the other -- in intact ones) (Fig. 1).

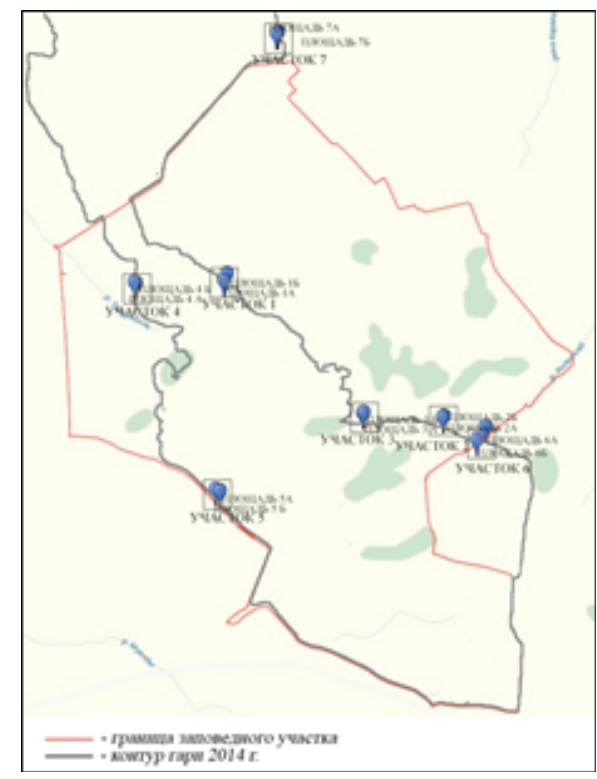

Figure 1: Location of monitoring sites and communities. 
Geobotanical descriptions were carried out through standard geobotanical techniques (ecologo-phytocenotic approach).

The Latin names of the species in the article are mainly given upon the summary of S.K. Cherepanov [21], in some cases on the Flora of Eastern Europe.

\section{Results}

In the first year following a fire event, the total plant cover of shrub-steppe herbaceous communities affected by a wildfire is recognized to be almost halved, and increasing nearly by $20 \%$ in the second year it fails to reach the indices typical of similar postfire communities. The plant cover dominated by bunchgrasses, especially of the genus Stipa, significantly decreases; the leaf litter is partially or completely burned out.

The abundance of species, both in the first and in the second year following a fire event, more or less differs between the postfire communities and their intact counterparts.

The assessments showed that the interval of mass flowering of species in the postfire communities is extended, as compared to intact ones (about one and a half weeks, depending on a habitat), which is most clearly seen in the spring period and somewhat leveling in the future.

In the first years after a fire event, in the postfire communities there is an increase in the abundance of ephemeroids (Valeriana tuberosa, species of the genus Tulipa, Allium tulipifolium, Poa bulbosa and others), some biennials (Sisymbrium polymorphum, Verbascum phoenicium, Falcaria vulgaris), perennials (Ferula caspica, F. tatarica), and occasionally dwarf semishrubs (Eremogone koriniana, Artemisia austriaca). Moreover, such "outbursts" of certain species are strongly evident in the areas exposed to overgrazing in the past, and for some of the species they are possible solely in such places.

One of the most obvious effects of fire regime on the plant cover is a direct impact on dominant and codominant species in plant communities, leading to a change in their abundance and cover fraction, and often their role in the community for a certain period. In the assessed communities, two scenarios of changes in the main geobotanical indices of the dominant species were observed:

1. steady post-fire mortality of all dominant and codominant species and their subsequent fluctuation in the same pre-fire ratio with a more or less equivalent loss of vegetation fraction; 
2. more significant damage to dominant and less fire-resistant co-dominant species followed by the succession in their role within the community with more quickly recovering co-dominant species.

The second embodiment change in the community can look like a post-fire displacement of Stipa zalesskii, Festuca valesiaca, Galatella villosa community by Festuca valesiaca, Stipa zalesskii, Galatella villosa fescue-feather community.

A re-assessment did not indicate any renewal of domination structure in such communities in the second year following a fire event, just a gradual increase in the fraction of the species.

It is obvious that changes in the composition of communities relate to all their constituent groups: grasses, forbs, half-shrubs, shrubs, etc.

The study claimed that among all cereal grasses that usually reach most noticeable post-fire abundance, Stipa zalesskii has the most downward and slowly restored phytocoenotic characteristics (especially the cover fraction). This species most often dominates and codominates in shrub-steppe communities and is found in all described communities. Reaching $1 / 2-1 / 3$ of the control (native) value in the first year, its fraction slows down the recovery rates in the second year and adds less than 10\% (usually $5-7 \%)$ or stays at last year's level.

Stipa lessingiana suffers to a lesser extent. It restores its vegetation fraction less intensively if it significantly prevailed in the native community and more intensively if it was a co-dominant species or was present in a small abundance. One of the most dynamically recovering components of the community is Festuca valesiaca. As can be seen from the above example, this species can even displace other dense-tussock grasses in the role of a dominant. Koeleria cristata greatly reduces the abundance in the first post-fire year and is intensively restored in the second. Besides, there is a slight increase in the abundance and cover of Koeleria cristata in the unimpaired areas in the second, more humid year of research. In Helictotrichon desertorum communities the dominating pattern shifts slightly and restores quickly.

Among the loose-tussock cereals, a mesoxerophytic shrub-steppe ephemeroid, Poa bulbosa, signalizes the most significant change in the abundance and cover fraction. It often appears in the post-fire areas in the second year following a fire event, and provided that it occurs in the communities in the first year, in the second -- it significantly increases the abundance and cover fraction. What is more, in the unimpaired areas, the species does not change these indicators, and in some areas in the second year, it generally leaves the ecosystem composition at all. 
Among the loose-tussock cereals, a shrub-steppe mesoxerophyte, Poa transbicalica, can be found in the communities described. It commonly occurs in the plant communities in the growing post-fire season, and just slightly increases the abundance in the second, as well as a shrub-steppe xerophytes, Agropyron pectinatum, characterized by a small abundance and often increasing the cover in the second year.

In plant ecosystems a shrub-steppe xerophytes, Galatella villosa, is known for being most considerably prone to abundance among forbs. In most cases it restores the abundance and cover fraction to the rates close to the control (and even slightly higher) values in the first growing post-fire season, occurring and increasing its abundance in the second year only in a few communities.

Such species as Galium ruthenicum, Medicago romanica, Salvia tesquicola, Scabiosa isetensis, often along with goldilocks, forming the basis of shrub-steppe ecosystems and appearing in the community in the first post-fire year, retain or gradually increase the vegetation fraction and abundance by the second year, although the first three of these species continue to have both of them lower than in the comparable intact communities.

Unlike the above-mentioned shrub-steppe mesoxerophytic sagebrush, Salvia tesquicola, another species of this genus that is also a common component of steppelike communities, Salvia stepposa xerophyte, was more abundant in the post-fire areas than in the control ones in both years.

Like Galatella villosa, Galium octonarium, reaches a noticeable post-fire abundance in most communities in the first year. At this time the vegetation fraction of this species is close or even noticeably larger than in non-disturbance areas. By the second year, the vegetation dynamics of Galium octonarium fraction varies subject to the community, always towards stabilization and approximation to the control communities. If the abundance and vegetation fraction do not reach the values endemic to the given area in the first year, it increases, and if they exceed, it decreases.

The abundance and cover fraction of such species as Adonis wolgensis, Astragalus onobrychis, A. scopaeformis, A. testiculatus, A. wolgensis, Veronica incana, Centaurea marschalliana, Euphorbia seguierana, Hieracium virosum, etc. since the first vegetation season correspond to these indices in the control areas and change further likewise.

In some communities, Pulsatilla patens shows a high abundance and cover fraction in the first post-fire year, which significantly decrease in the second year up to the control values. The same dynamics was observed for a perennial bulbous ephemeroid, Tulipa biebersteiniana, and in some areas also for mesoxerophytic biennials, Sisymbrium polymorphum and Verbascum phoenicium. 
In the second year, the abundance and diversity of perennial bulbous xeromesophytes increase in the post-fire communities. Sometimes Allium globosum, $A$. flavescens and Gagea pusilla in the second year join Allium tulipifolium, A. lineare that are already present in the plant communities.

In its characteristic small abundance, Erysimum leucanthemum occurs in the post-fire communities only in the second year.

A xeromesophytic annual, Polygonum patulum, and a biannual, Falcaria vulgaris, appearing in the post-fire grassland compositions in the first year, significantly increase the abundance and cover fraction (twice or more) in the following year in the areas that were exposed to overgrazing in the past. In other cases, these indicators correspond to those in the surrounding intact communities. Chenopodium strictum also reaches the abundance in the post-fire pastoral-digressed communities in both years.

Galatella divaricata, Cephalaria uralensis in different communities demonstrate quite opposite trends in the vegetation dynamics, abundance and cover fraction.

Hylotelephium stepposum shows a clear tendency to leave the plant communities during succession changes following a fire event. Of the five post-fire communities in which this species was found in the first post-fire year, in three it did not occur in the second year. However, in these cases, it was not recorded in the unimpaired (control) communities either. Perhaps its very occurrence in the first post-fire growing season is associated with the impact of this factor. Astragalus rupifragus that is found in the post-fire communities during the first growing season following a fire event, often drop out of the post-disturbance herbal communities. Just within one study site Eremogone longifolia, Seseli libanotis and Hedysarum razoumovianum were found and dropped out of the post-fire community in the second year. Gypsophila altissima disappears from the post-fire grass composition or reduces the degree of vegetation fraction, while in the more humid second year of research, this species retains the values of abundance and vegetation fraction (and even appears in the community it was initially absent) in unimpaired areas. In the three communities in the first year following a fire event, Taraxacum serotinum was found, in two of them it was not found during the re-assessment of the communities the following year and only in one geobotanic area located in the old-age deposit, it increased markedly.

In the assessed communities, only one species of sedges, Carex supine, was found. It tends to restore its abundance and cover fraction to the control values from the first year and preserves this result in the next year.

The phytocenotic role of dwarf semishrubs varies in the post-fire communities in different ways. Thus, Artemisia marschalliana in the first post-fire year in some areas 
is characterized by a lower abundance and vegetation fraction than in the control communities, and shows a rise in the indices in the second year, while in some areas, it demonstrates a noticeable abundance in the unimpaired communities and is completely absent in the post-fire ones. Artemisia austriaca appears in large abundance in the areas that were subjected to overgrazing in the past, and even increases in the second year. Eremogone koriniana reaches high (in some places much higher than in the neighboring control areas) values of abundance and vegetation fraction in the post-fire communities in the first year, reducing these figures in the second year. Sometimes it occurs in the post-fire areas, and can be absent in the control intact. Oxytropis spicata and Thymus marschallianus from the first growing season corresponded to the phytocenotic role in the control sites and changed the abundance and vegetation fraction in the future in the same way.

The only shrub in the studied communities, Spiraea crenata, retains its abundance after a wildfire, but the vegetation fraction decreases significantly and in the second year following a fire event it remains consistently lower than in the comparable intact areas.

\section{Conclusion}

In the first two years following a fire event, full restoration of the shrub-steppe plant cover does not occur: a number of characteristics of post-fire communities (total plant cover, abundance and fractions of certain species) do not reach those of the control areas.

Resulting from a decrease in albedo and, following the soil heating conditions, the phenological phases are displaced (by about one and a half weeks, subject to a habitat) in the post-fire areas, as contrary to the unimpaired ones. The shift is especially visible in spring and is somewhat leveling off in the future. Sometimes in the first years following a fire event, the abundance and diversity of ephemeroids increases in the post-fire areas.

Just a few plant species unidirectionally respond to changes in environmental conditions after a fire, increasing or decreasing their abundance. The dynamics of the invasive role of most species in plant communities is often multidirectional and depends, apparently, on the initial conditions of a community, as well as on the course and conditions of succession processes. The most dynamic components of the floristic composition of communities are biennials, as well as annuals. Changes in the floristic composition of communities in the form of a significant increase in the role of individual 
species (most often ephemeroids and biennials) during one growing season is endemic to the areas that were exposed to overgrazing in the past.

As a result of plant cover burning, there can be a change of dominant and codominant species in plant communities, while in the second year of the research there is no return to the original domination structure. Most often Festuca valesiaca becomes invasive in the shrub-steppe communities during the suppression following a fire event.

\section{Acknowledgment}

The work was carried out in the framework of RFBR grant and under the budget topic of the Institute of Steppe, Ural Branch RAS No.GR AAAA-A17-117012610022-5.

\section{References}

[1] Popov, A.V. (2004). Steppe fires and biodiversity conservation in the protected areas of the Northern Caspian region. Proceedings of the international conference dedicated to the 15th anniversary of the Orenburg State Reserve, pp. 152--153.

[2] Yunusbayev, U.B., Abdulina, K.Kh., Yanturin, S.I. (2007). The role of fires in the formation of aboveground phytomass of steppe grasslands of the Trans-Urals of the Republic of Bashkortostan. Agrarian Russia, no. 5, pp. 24--25.

[3] Sambuu, A.D., Khomushku, N.G. (2015). The problem of forest and steppe fires on the territory of the Republic of Tyva. Modern problems of science and education, no. 2-2. Retrieved from: http://science-education.ru/ru/article/view?id=21607 (access date: 02/26/2019).

[4] Sambuu, A.D., Dapylday, A.B. (2016). Steppe vegetation fires on the territory of Tuva and their consequences. Proceedings of the 1st International Scientific and Practical Conference "Preservation of the diversity of flora of Tuva and cross-border regions of Central Asia: history, modernity, prospects". Tuva, pp. 135--141.

[5] Tkachuk, T.E. (2015). Dynamics of steppe fires in the south of Dauria in the first decade of the 21st century. Scientific notes of Trans-Baikal State University. Series: Natural Sciences, no. 1(60), pp. 72--79.

[6] Tkachuk, T.E., Denisova, Yu.Yu. (2015). "The Effect of Experimental Burning on the Structure of Steppe Ecosystems in the South of Dauria", Proceedings of the VII International Symposium "Steppes of Northern Eurasia", pp. 847--849.

[7] Drogobych, N.E. (2000). Post-pyrogenic dynamics of the elevated phytomass of the steppe ecosystems of the Black Sea region. Materials of the II International 
Symposium "Steppes of Northern Eurasia: a strategy for the conservation of natural diversity and steppe environmental management in the 21st century", pp. 148--150

[8] Lysenko, G.N. (2006). Stability of steppe phytocenostructures: thermodynamic aspect. Materials of the IV International Symposium "Steppes of Northern Eurasia", pp. 449--451.

[9] Ruprecht, E., Enyedi, M.Z., Szabo, A., Fenesi, A. (2016). Biomass removal by clipping and raking vs burning for the restoration of abandoned Stipa-dominated European steppe-like grassland. Applied Vegetation Science, vol. 19, pp. 78--88.

[10] Kertész, M., Aszalós, R., Lengyel, A., Ónodi, G. (2017). Synergistic effects of the components of global change: Increased vegetation dynamics in open, forest-steppe grasslands driven by wildfires and year-to-year precipitation differences. PLoS ONE, vol. 12. Retrieved from: http://journals.plos.org/plosone/article?id=10.1371/ journal.pone.0188260,2017.

[11] Rostagno, C.M., Guillermo, D.E., del Valle Héctor, F. (2006). Postfire Vegetation Dynamics in Three Rangelands of Northeastern Patagonia, Argentina. Rangeland Ecol. Manage, vol. 59, pp. 163--170.

[12] Bates, J.D., Rhodes, E., Davies, K., Sharp, R. (2009). Grazing after fire in the sagebrush steppe. Rangeland Ecology and Management, vol. 62, pp. 98--110.

[13] Twidwell, D., Rogers, W.E., McMahon, E.A., Thomas, B.R., Kreuter, U.P., Blankenship, T.L. (2012). Prescribed Extreme Fire Effects on Richness and Invasion in Coastal Prairie. Invasive Plant Science and Management, vol. 5, pp. 330--340.

[14] Winter, S.L., Allred, B.W., Hickman, K.R., Fuhlendorf, S.D. (2015). Tallgrass prairie vegetation response to spring fires and bison grazing. The Southwestern Naturalist, vol. 60(1), pp. 30--35.

[15] Hanna, S.K., Fulgham Hanna, K.O. (2015). Post-fire vegetation dynamics of a sagebrush steppe community change significantly over time. California Agriculture, vol. 69(1), pp. 36--42.

[16] Davies, K.W., Gearhart, A., Boyd, Ch.S., Bates, J.D. (2017). Fall and spring grazing influence fire ignitability and initial spread in shrub steppe communities. International Journal of Wildland Fire, vol. 26, pp. 485--490.

[17] Gullap, M.K., Erkovan, S., Erkovan, H.I., Koc, A. (2018). Effects of Fire on Litter, Forage Dry Matter Production, and Forage Quality in Steppe Vegetation of Eastern Anatolia, Turkey. Journal of Agricultural Science and Technology, vol. 20 (1), pp. 61--70.

[18] Mata-Gonzáleza, R., ReedDustin, C.M., Rodhouse Th.J. (2018). Contrasting Effects of Long-Term Fire on Sagebrush Steppe Shrubs Mediated by Topography and Plant Community. Rangeland Ecology \& Management, vol. 71(3), pp. 336--344. 
[19] Safronova, I.N., Kalmykova, O.G. (2012). Issues of zonality and the role of nature reserves in their solution. News of the Samara Scientific Center of the Russian Academy of Sciences, no. 1(6), P. 1638--1641.

[20] The Red Book of Orenburg Oblast: soils. (2001), pp. 2--295.

[21] Cherepanov, S.K. (1995). Vascular plants of Russia and cross-border states (within the former USSR), pp. 3--990. 